Pengolahan Limbah Cair Industri Kelapa Sawit

Menggunakan Reaktor UAF (Upflow Anerobic Filter) ....Djoko Purwanto

\title{
PENGOLAHAN LIMBAH CAIR KELAPA SAWIT MENGGUNAKAN REAKTOR UAF (UPFLOW ANAEROBIC FILTER)
}

\author{
Processing Waste Water Palm Oil \\ Using of Reactor UAF (Upflow Anaerobic Filter) \\ Djoko Purwanto \\ Balai Riset dan Standardisasi Industri Banjarbaru \\ JI. P. Batur Barat No.2. Telp.0511-4772461-4774861 Banjarbaru \\ E-mail : baristand.banjarbaru@gmail.com \\ Diterima 12 Nopember 2012, disetujui 25 Mei 2013
}

\begin{abstract}
ABSTRAK
Pengolahan limbah cair industri kelapa sawit menggunakan reaktor UAF. Tujuan penelitian membuat prototipe pengolahan air limbah yang meliputi bak penampung, bak sedimentasi dan reaktor UAF, kemudian dilakukan uji pengolahan air limbah. Filter yang digunakan yaitu potongan-potongan pipa paralon, dan pada bagian bawah reaktor UAF diisi lumpur. Untuk mempercepat penurunan TSS air limbah, pada bak sedimentasi ditambah PAC 0,5\% (Poly Aluminium Chlorida). Proses aklimatisasi dilakukan selama 30 hari, dan proses pengolahan limbah pada reaktor UAF dilakukan selama 24 jam, kemudian dilakukan analisa baku mutu air limbah sebelum dan sesudah hasil pengolahan pada reaktor. Hasil analisa air limbah sebelum pengolahan diperoleh $\mathrm{pH} 7,36$; BOD 980 ppm; COD 1960,6 ppm; TSS 5089 ppm; minyak lemak 43 ppm; $\mathrm{NH}_{3}-\mathrm{H} 2,80$ ppm dan $\mathrm{N}$-Total 246,64 ppm. Hasil pengolahan air limbah selama 24 jam dalam reaktor UAF $\mathrm{pH}$ 6,64; BOD 28,84 ppm; COD 56,94 ppm; TSS 48 ppm; minyak lemak <1 ppm; $\mathrm{NH}_{3}-\mathrm{N}$ $0,082 \mathrm{ppm}$ dan $\mathrm{N}$ Total $11,31 \mathrm{ppm}$.
\end{abstract}

Kata kunci : limbah cair, kelapa sawit, anaerobic, reaktor UAF, pipa PVC

\section{ABSTRACT}

The treatment of waste water palm oil industry using UAF reactor. The research purpose was to make a prototype that includes a wast ewater tank, a sedimentation tank and UAF reactor, and then trial the waste water treatment. Filters used were pieces of PVC pipe, and at the bottom of the UAF reactor filled with sludge. To quickly decrease waste water TSS, the sedimentation addition 0.5\% PAC (Poly Aluminium Chloride). Acclimatization process doing duration 30 days, and the waste water treatment process at UAF reactor doing duration 24 hours, then doing analyzed the raw waste water quality before and after the processing of the reactor. Results of analysis of wastewater before treatment is pH 7.36; BOD 980 ppm; COD 1960.6 ppm ; TSS 5089 ppm ; fatty oil 43 ppm; $\mathrm{NH}_{3}-\mathrm{H} 2,80 \mathrm{ppm}$ and $\mathrm{N}$-Total $246.64 \mathrm{ppm}$. The results of waste water treatment for 24 hours in the UAF reactor is pH 6.64; BOD 28.84 ppm; COD 56.94 ppm; TSS 48 ppm; fatty oils <1 ppm; $\mathrm{NH}_{3}-\mathrm{N} 0.082 \mathrm{ppm}$ and $\mathrm{N}$-Total $11.31 \mathrm{ppm}$.

Keywords: waste water, palm oil, anaerobic, UAF reactor, tube PVC

\section{PENDAHULUAN}

Di Kalimantan Selatan terdapat perkebunan kelapa sawit seluas 292.800 $\mathrm{Ha}$, dengan jumlah industri pengolahan kelapa sawit 23 perusahaan, dan menghasilkan minyak kelapa sawit atau CPO (Crude Palm Oil) 503.155 ton

pertahun (Solihin, 2012). Menurut Ahmad (2003), dalam industri pengolahan kelapa sawit akan diperoleh limbah industri dalam bentuk padat, cair dan gas, untuk limbah cair setiap ton minyak sawit yang dihasilkan akan menghasilkan limbah cair 
2,5 $\mathrm{m}^{3}$. Apabila limbah cair ini tidak dilakukan pengolahan dan langsung dibuang ke badan sungai maka akan mencemari lingkungan, karena baku mutu seperti COD (Chemical Oxygen Demand), TSS (Total Suspended Solid), BOD (Biological Oxygen Demand), minyak lemak, amoniak, dan N-Total akan melebihi ambang batas baku mutu yang telah ditetapkan oleh Kementerian Lingkungan Hidup.

Pengolahan limbah cair yang diterapkan di pabrik kelapa sawit, dilakukan secara sederhana menggunakan kolam anaerobik, cara ini memerlukan lahan yang cukup luas, dan waktu pengolahan cukup lama (Farida. $\mathrm{H}, 2009$ ). Pada umumnya nilai baku mutu limbah cair yang dibuang ke badan sungai belum dapat memenuhi baku mutu yang telah ditetapkan oleh Kementerian lingkungan Hidup. Menurut Darwin (2004), Pengolahan limbah cair secara anaerobik merupakan proses degradasi senyawa organik seperti karbohidrat, protein dan lemak yang terdapat dalam limbah cair yang dilakukan oleh bakteri tanpa kehadiran oksigen. Reaktor Hybrid Anaerob adalah reaktor pengolahan limbah cair yang memanfaatkan aktivitas mikroorganisme untuk menghilangkan atau mengurangi kandungan zat organik yang ada didalam limbah cair, dengan menggunakan sistem reaktor ini mampu memperkecil kehilangan biomassa dan menghasilkan nilai COD yang lebih rendah dari keadaan semula (Adrianto, 2011).

Penelitian Pengolahan limbah cair industri kelapa sawit menggunakan reaktor UAF, dan sebagai filter menggunakan potongan-potongan pipa paralon telah dilakukan. Tujuan penelitian membuat prototipe alat pengolahan limbah cair menggunakan reaktor UAF (Upflow Anerobic Filter), dan mengetahui nilai penurunan kadar baku mutu limbah cair kelapa sawit (TSS, COD, BOD, $\mathrm{NH}_{3}-\mathrm{N}$, $\mathrm{N}$-Total, dan minyak lemak).

\section{BAHAN DAN METODE}

Penelitian menggunakan bahan baku berupa limbah cair kelapa sawit, dan lumpur yang diambil dari kolam anaerobik pabrik kelapa sawit PT. Smart Tbk. Kabupaten Tanah Laut. Bahan penolong yang digunakan yaitu PAC (Poly Aluminium Chlorida), dan bahan kimia lainya untuk analisa parameter uji BOD, COD, Amoniak, $\mathrm{N}$-Total, dan minyak lemak. Peralatan yang digunakan dalam penelitian pembuatan prototipe alat pengolahan limbah cair antara lain : besi UNP 10, pipa stainles stel type 306, pipa PVC, tandon/penampung, circulation pump, butterfly valves, filter medium, pipa paralon dan lain-lain.

\subsection{Pembuatan Prototipe alat pengolahan limbah cair}

Prototipe alat pengolahan limbah cair meliputi bak penampung volume $3 \mathrm{~m}^{3}$, bak Sedimentasi $4 \mathrm{~m}^{3}$ (panjang 1,00 meter, lebar 2,44 meter, tinggi 1,22 meter), reaktor UAF terdiri dari dua chamber/bagian dengan panjang 2,44 meter; lebar 0,80 meter; tinggi 1;22 meter, tiap chamber terdapat filter yang terbuat dari potonganpotongan pipa paralon (Gambar penampang reaktor UAF dapat dilihat pada Gambar 2), dan rangkaian bentuk prototipe alat pengolahan limbah cair dapat dilihat pada Gambar 1

\subsection{Analisa dan Pengolahan air limbah industri kelapa sawit}

Air limbah yang digunakan diambil dari kolam anerobik, hal ini untuk mengetahui kondisi awal besarnya kadar baku mutu. Metode uji yang digunakan dalam analisa parameter baku mutu limbah cair mengacu pada Standar Nasional Indonesia (SNI: 06-6989.11-2004 untuk $\mathrm{pH}$; 6989.2:2009 untuk COD ; SNI : 066989.30-2005 untuk $\mathrm{NH}_{3}-\mathrm{N}$; SNI : 066989.3-2004 untuk TSS; SNI : 06-6989.522005 untuk N-total; SNI : 6989.72-2009 untuk BOD; dan SNI : 06-6989.10-2004 untuk minyak lemak) tentang analisa air limbah. Kemudian dipindahkan ke bak penampungan, dan bak sedimentasi. Didalam bak sedimentasi ditambahkan koagulan (PAC) sebanyak 0,5\%, hal ini karena dari hasil analisa awal air limbah industri kelapa sawit diperoleh nilai TSS diatas 5000 ppm, sehingga untuk mempercepat penurunan kadar TSS diperlukan penambahan koagulan. Proses 
koagulasi dilakukan selama 60 menit. Setelah itu dilakukan proses aklimatisasi, dengan tujuannya untuk penyesuaian dan berkembang biaknya mikroorganisme pada lumpur yang diambil dari kolam anaerobik pabrik kelapa sawit, dan fiter sebagai tempat untuk menempel dan berkembang biaknya bakteri. Pemindahan limbah cair dari bak sedimentasi ke reaktor UAF, namun sebelumnya pada bagian bawah didalam rektor UAF diisi lumpur, kemudian pengisian air limbah ke chamber 1 dan 2 , dan diisi hampir penuh. Proses aklimatisasi dilakukan selama 4 - 30 hari, (hal ini dalam kurun waktu tersebut terjadi perkembangan biaknya mikroorganisme), dan setiap periode 4 hari dilakukan pengambilan, air limbah pada chamber 1 dan 2 untuk dianalisa kadar baku mutunya. Setelah dilakukan proses aklimatisasi, air limbah didalam reaktor UAF dibuang dialirkan ke instalasi pengolahan air limbah laboratorium, dan disisakan kurang lebih sepertiga dari volume reaktor, kemudian dilakukan pengisian air limbah yang baru diambil dari perusahaan, dan diisikan ke reaktor, dan pada bak sedimentasi ditambah koagulan (PAC) dengan perlakuan yang sama seperti pada proses akllimatisasi. Pengaliran air limbah dari bak sedimentasi ke reaktor chamber 1 dan 2 diatur dengan kecepatan alir $1 \mathrm{~m}^{3}$ per jam, waktu tinggal limbah cair pada reaktor selama 24 jam (kondisi ini diperkirakan dalam waktu tersebut kadar awal limbah cair mampu diminimaliser oleh mikro organisme), kemudian diambil sampel air limbah pada chamber 1 dan 2 untuk dianalisa parameter baku mutunya.

\section{HASIL DAN PEMBAHASAN}

\subsection{Analisa air limbah sebelum proses pengolahan}

Hasil analisa parameter baku mutu air limbah kelapa sawit sebelum pengolahan atau yang baru diambil dari pabrik kelapa sawit dapat dilihat pada Tabel 1. Dari Tabel 1 dapat dikemukakan bahwa nilai $\mathrm{pH}$ dan amoniak $\left(\mathrm{NH}_{3}-\mathrm{N}\right)$ memenuhi baku mutu limbah cair yang ditetapkan oleh Kementerian Lingkungan Hidup. Namun untuk parameter BOD,
COD, TSS, minyak lemak, dan N-Total diatas ambang batas baku mutu. Agustina (2005), mengatakan kandungan BOD dan COD yang cukup tinggi pada limbah cair kelapa sawit disebabkan akibat tingginya kandungan bahan senyawa organik, dan ini akan menurunkan kualitas lingkungan dan oksigen terlarut, bila tidak dirombak oleh bakteri.

\subsection{Poses koagulasi}

Proses koagulasi tujuannya menurunkan kekeruhan atau partikelpartikel padatan tersuspensi yang tinggi, dengan penambahan bahan koagulan berbentuk zat-zat organik atau anorganik. Penambahan koagulan dapat memakai elektroda alumunium sebagai sumber ion alumunium, dan ion ini akan bereaksi dengan air membentuk alumunium hidroksida yang berfungsi sebagai koagulasi. Penggunaan koagulan jenis PAC dapat menurunkan kadar TSS (Darwin, 2004). Hasil analisa kadar TSS air limbah sebelum pengolahan koagulasi yaitu 5089 ppm (Tabel 1), setelah dilakukan peenambahan PAC $0,5 \%$, dan didiamkan selama 60 menit dalam bak sedimentasi, dapat menghasilkan penurunan TSS sebesar 1090 ppm (Tabel 1) atau penurunan sekitar $80 \%$.

\subsection{Proses aklimatisasi}

Proses aklimatisasi dilakukan dengan waktu tinggal limbah cair selama 30 hari, untuk hasil analisa baku mutu limbah cair setiap waktu tinggal periode 4 hari hingga 30 hari dapat dilihat pada Tabel 3 . Berdasarkan dari Tabel 3 nilai $\mathrm{pH}$ dengan waktu tinggal 4 dan 8 hari adalah 6,48 dan 7,28 memenuhi baku mutu limbah cair kelapa sawit yaitu 6-9 (Anonim, 1995). Nilai BOD, COD, TSS, minyak lemak, $\mathrm{NH}_{3}-\mathrm{N}$, dan $\mathrm{N}$-Total pada Tabel 3 terjadi penurunan yang cukup besar, dan ini menunjukkan bahwa mikroba dapat menguraikan zat organik dan anorganik yang terdapat pada air limbah kelapa sawit. Menurut Adrianto (2011), penurunan COD menunjukkan bahwa mikro organisme bekerja dengan baik sehingga proses dapat berlangsung, karena dapat mendegradasikan senyawa - senyawa organik didalam limbah cair. Dari 
Tabel 3., setiap penambahan waktu tinggal limbah cair selama 4 hari pada reaktor UAF diperoleh fluktuasi nilai kadar baku mutu, tetapi pada saat tertentu ada penambahan. Penggunaan variasi waktu aklimatisasi bertujuan untuk mengetahui kemampuan waktu optimal berkembang biaknya mikroba. Waktu tinggal limbah cair selama 30 hari pada rekator UAF menunjukkan sudah cukup optimal, hal ini terlihat dari hasil analisa kadar BOD, COD, TSS, minyak lemak, amoniak, dan N-Total dari penyimpanan 20 hari dengan 30 hari tidak berbeda jauh hasil analisanya. Penggunaan filter dari potongan-potongan pipa paralon sebagai tempat untuk menempelnya bakteri sehingga menyebabkan terjadinya surplus bakteri atau mikroba, dan akan digunakan untuk menguraikan bahan-bahan organik atau padatan terlarut yang ada pada air limbah, dan sebagai nutrisi untuk mikroorganisme adalah unsur nitrogen yang terdapat pada lumpur, unsur ini juga harus mencukupi untuk kebutuhan bakteri. Filter berfungsi dimana bakteri dapat menempel dan air limbah dapat lewat, pada waktu air limbah lewat akan diuraikan oleh mikro organisme/ bakteri tersebut, sehingga terjadi pengurangan kandungan zat organik pada effluent.

\subsection{Proses pengolahan air limbah pada reaktor UAF}

Hasil analisa air limbah sebelum diolah yaitu nilai $\mathrm{pH} 7,36$; BOD 980 ppm; COD 1960,6 ppm; TSS 5089 ppm; minyak lemak 43 ppm; $\mathrm{NH}_{3}-\mathrm{N}$ 2,80 ppm dan $\mathrm{N}$-Total 246,64 ppm. Setelah dilakukan penambahan PAC $0,5 \%$ dalam bak sedimentasi dan dibiarkan selama 60 menit, dan dilakukan analisa diperoleh nilai pH 3,48; BOD 610,25 ppm; COD 1225,7 ppm; TSS 605 ppm; minyak lemak 35 ppm; $\mathrm{NH}_{3}-\mathrm{N} 2.10$ ppm dan $\mathrm{N}$ - Total 230,45 ppm. Penambahan PAC $0,5 \%$ dapat menurunkan TSS sebesar $80 \%$. Hasil uji operasional dengan waktu tinggal limbah cair dalam reaktor UAF selama 24 jam, diperoleh nilai $\mathrm{pH}$ 6,5-6,64; BOD 28,8-31,2 ppm; COD 56,94-65,77 ppm; TSS 48-57 ppm; minyak lemak <1 ppm dan $\mathrm{NH}_{3} \mathrm{~N}$ $0,082 \mathrm{ppm}$, nilai ini memenuhi syarat baku mutu KEP. 51/MENLH/10/1995 tentang Baku Mutu Limbah Cair bagi kegiatan industri kelapa sawit. Hasil pengolahan air limbah menggunakan reaktor UAF dan filter dari potongan-potogan pipa paralon diperoleh nilai penyisihan BOD sekitar 97\%; COD 97\% dan TSS 91\%. Untuk nilai penyisihan COD ini lebih besar bila dibandingkan dengan hasil penelitian yang dilakukan oleh Firdha (2010) dengan menggunakan filter batu, yaitu sebesar 90\%, sedangkan Laturkey (2010), menggunakan filter pelepah kelapa sawit menghasilkan penyisihan COD sebesar $84 \%$, dan $82,6 \%$ untuk menggunakan tandan kosong kelapa sawit.

\section{KESIMPULAN}

Proses koagulasi menggunakan PAC 0,5\% dengan waktu tinggal limbah cair pada bak sidementasi selama 60 menit, dapat menurunkan kadar TSS sebesar $80 \%$.

Proses aklimatisasi selama 30 hari cukup optimal untuk menghasilkan perkembangan biakan bakteri dan untuk mendegradasi zat oraganik limbah cair kelapa sawit pada reaktor UAF.

Hasil uji operasional reaktor UAF selama 24 jam diperoleh nilai $\mathrm{pH}$ 6,65; TSS 48-57 ppm; BOD 28,8-31,2 ppm; COD 59,94-65,77 ppm; minyak lemak <1; dan $\mathrm{NH}_{3}-\mathrm{N}$ 0,82 ppm memenuhi syarat baku mutu limbah cair industri kelapa sawit.

Prototipe alat pengolahan limbah cair dengan reaktor UAF dan filter potonganpotongan pipa paralon dapat menyisihkan BOD 97\%; COD 97\% dan TSS 91\%.

\section{DAFTAR PUSTAKA}

1. Anonim, 1995. Keputusan Menteri Negara Lingkungan Hidup. Nomor : KEP.51/MENLH/10/1995 Tentang Baku Mutu Limbah Cair Bagi Kegiatan Industri. Baku Mutu Limbah Cair untuk Industri Minyak Sawit.

2. Anonim, 2006. Pedoman Pengolahan Limbah Industri Kelapa Sawit. Subdit Pengelolaan Lingkungan Direktorat 
Pengolahan Hasil Pertanian Ditjen PPHP. Departemen Pertanian. Jakarta.

3. Ahmad, A.T.; Setiadi; M, Syafila; dan O.B. Liang. 2003. Bioreaktor Berpenyekat Anaerob untuk Pengolahan Limbah Cair Industri yang mengandung Minyak dan Lemak. Pengaruh Pembebanan Organik terhadap Kinerja Bioreaktor. Bioteknologi. ITB. Bandung.

4. Agustina. 2005. Penggunaan Teknologi Membran pada Pengolahan Air Limbah Industri KelapaSawit. Workshop Teknologi Industri Kimia dan Kemasan. Jakarta.

5. Adrianto, A.; Syarfi ; Mellissa, A. 2011. Penyisihan Chemical Oksigen dan Produksi Biogas limbah Cair Pabrik Kelapa Sawit dengan Bioreaktor hibrid Anaerob Bermedia Cangkang Sawit. Prosiding Seminar Nasional. Teknik Kimia Kejuangan. Yogyakarta.

6. Darwis, Y.N,.2004. Pengolahan Limbah Cair Pabrik Kelapa Sawit yang berasal dari Kolam Akhir (Final Pond) dengan Proses Koagulasi melalui Elektrolisis. Jurnal Sains Kimia. 8 (2). Jakarta.

7. Farida, H. 2009. Pengolahan Limbah Cair Pabrik Kelapa Sawit dari Unit Dealing Ponds menggunakan Membran Mikrofiltrasi. Thesis Sekolah Pasca Sarjana.USU.Medan.
8. Firdha, I. 2010. Penentuan Waktu Tinggal Hidrolik terhadap Penyisihan COD Limbah Cair Pabrik Kelapa Sawit dengan Bioreaktor Hibrid Anaerob Bermedia Batu. Laporan Penelitian Jurusan Teknik Kimia Universitas Riau. Pekanbaru.

9. Laturkey, Y. A, A. Ahmad dan S,Z, Anuraini. 2010. Uji Kinerja Bioreaktor Hibrid Anaerob Bermedia Tandan Kosong dan Pelepah Sawit dalam Penyisihan COD Limbah Cair Pabrik Minyak Sawit. Prosiding Seminar Teknik Kimia Soehadi Reksowardojo. ITB. Bandung.

10. Solihin. 2012. Rencana Pengembangan Industri Berbasis Minerba dan dukungan Sarana dan Prasarana di Provinsi Kalimantan Selatan. Makalah Disampaikan Pada FGD Penyusunan Strategi Pengembangan Investasi Industri, di Hotel Banjarmasin Internasional, Tanggal 29 Juni 2012. 
Tabel 1. Hasil analisa air limbah sebelum dan sesudah penambahan PAC

\begin{tabular}{cccccc}
\hline No. & Parameter uji & Satuan & $\begin{array}{c}\text { Sebelum } \\
\text { Pengolahan }\end{array}$ & $\begin{array}{c}\text { Setelah } \\
\text { Penambahan } \\
\text { PAC 0,5\% }\end{array}$ & $\begin{array}{c}\text { Baku Mutu Limbah Cair untuk } \\
\text { Industri Minyak Sawit } \\
\text { Kep. 51/MENLH/10/1995 }\end{array}$ \\
\hline 1. & $\mathrm{pH}$ & - & 7,36 & 3,48 & $6-9$ \\
\hline 2. & $\mathrm{BOD}$ & $\mathrm{mg} / \mathrm{l}$ & 980 & 830 & 250 \\
\hline 3. & $\mathrm{COD}$ & $\mathrm{mg} / \mathrm{l}$ & $1.960,6$ & $1.756,45$ & 500 \\
\hline 4. & $\mathrm{TSS}$ & $\mathrm{mg} / \mathrm{l}$ & 5.089 & 1.090 & 300 \\
\hline 5. & Minyak dan lemak & $\mathrm{mg} / \mathrm{l}$ & 43 & 35 & 30 \\
\hline 6. & $\mathrm{NH}_{3}-\mathrm{N}$ & $\mathrm{mg} / \mathrm{l}$ & 2,80 & 2,10 & 20 \\
\hline 7. & $\mathrm{~N}$-total & $\mathrm{mg} / \mathrm{l}$ & 246,64 & 230,45 & 45 \\
\hline
\end{tabular}

Tabel 2. Hasil analisa proses aklimatisasi pada reaktor UAF selama 30 hari

\begin{tabular}{lllllllllll}
\hline \multirow{2}{*}{ No. } & \multirow{2}{*}{ Parameter Uji } & \multirow{2}{*}{ Satuan } & \multicolumn{7}{c}{ Waktu Proses Aklimatisasi (hari) } \\
\cline { 5 - 12 } & & 4 & 8 & 12 & 16 & 20 & 24 & 26 & 30 \\
\hline 1. & pH & - & 6,48 & 7,28 & 5,34 & 5,44 & 5,44 & 4,98 & 5,65 & 5,89 \\
\hline 2. & BOD & $\mathrm{mg} / \mathrm{l}$ & 123 & 152,5 & 92 & 156 & 156 & 81 & 37 & 60 \\
\hline 3. & COD & $\mathrm{mg} / \mathrm{l}$ & 242 & 416,73 & 190 & 302,90 & 302,93 & 163,64 & 74,67 & 130,90 \\
\hline 4. & TSS & $\mathrm{mg} / \mathrm{l}$ & 142 & 170 & 55 & 62 & 62 & 49 & 40 & 52 \\
\hline 5. & Minyak/lemak & $\mathrm{mg} / \mathrm{l}$ & 3 & 6 & $<1$ & $<1$ & $<1$ & $<1$ & $<1$ & $<1$ \\
\hline 6. & NH3N & $\mathrm{mg} / \mathrm{l}$ & 0,272 & 0,382 & 0,020 & 0,020 & 0,027 & 0,004 & 0,005 & 0,008 \\
\hline 7. & N-total & $\mathrm{mg} / \mathrm{l}$ & 33,43 & 35,14 & 1,48 & 1,48 & 3,07 & 1,30 & 1,08 & 2,08 \\
\hline
\end{tabular}

Tabel 3. Hasil proses pengolahan air limbah selama 24 jam pada reaktor UAF

\begin{tabular}{|c|c|c|c|c|c|}
\hline \multirow{2}{*}{ No. } & \multirow{2}{*}{ Parameter Uji } & \multirow{2}{*}{ Satuan } & \multicolumn{2}{|c|}{ Reaktor UAF } & \multirow{2}{*}{$\begin{array}{c}\text { Baku Mutu Limbah Cair untuk } \\
\text { Industri Minyak Sawit } \\
\text { Kep- 51/MENLH/10/1995 }\end{array}$} \\
\hline & & & Chamber 1 & Chamber 2 & \\
\hline 1. & $\mathrm{pH}$ & - & 6,5 & 6,64 & $6-9$ \\
\hline 2. & BOD & $\mathrm{mg} / \mathrm{l}$ & 31,2 & 28,8 & 250 \\
\hline 3. & COD & $\mathrm{mg} / \mathrm{l}$ & 65,772 & 56,938 & 500 \\
\hline 4. & TSS & $\mathrm{mg} / \mathrm{l}$ & 57 & 48 & 300 \\
\hline 5. & Minyak/lemak & $\mathrm{mg} / \mathrm{l}$ & $<1$ & $<1$ & 30 \\
\hline 6. & $\mathrm{NH} 3 \mathrm{~N}$ & $\mathrm{mg} / \mathrm{l}$ & 0,082 & 0,082 & 20 \\
\hline
\end{tabular}




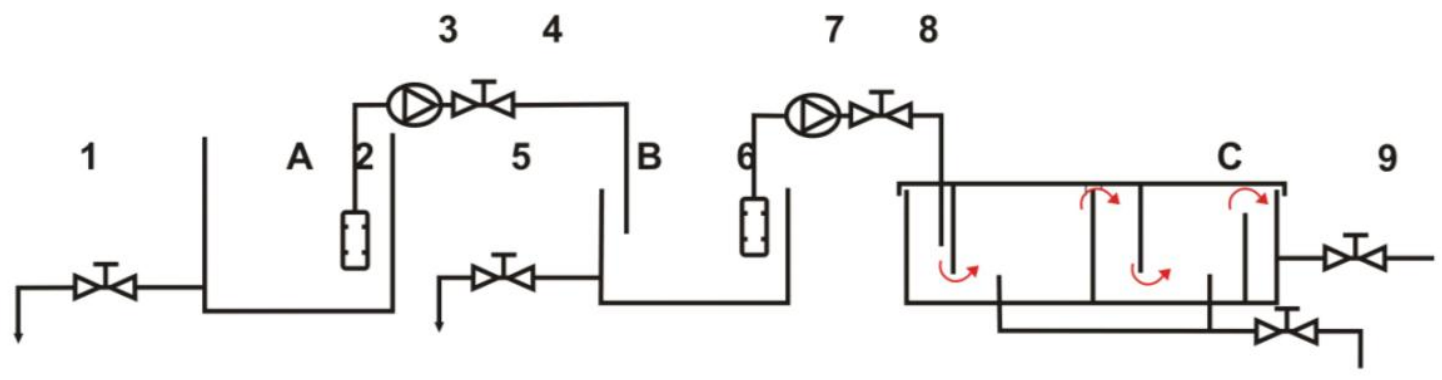

Gambar 1. Desain Rangkaian Peralatan Pengolahan Air Limbah.

Keterangan :
A. Tangki penampungan
1. Drain Valvee
6. Circulation pump
B. Tangki pengendapan
2. Circulation pump
7. Butterfly pump
C. Tangki reaktor UAF
3. Butterfly pump
4. Drain valve
8. Drain valve
5. Drain valve
9. Drain valve

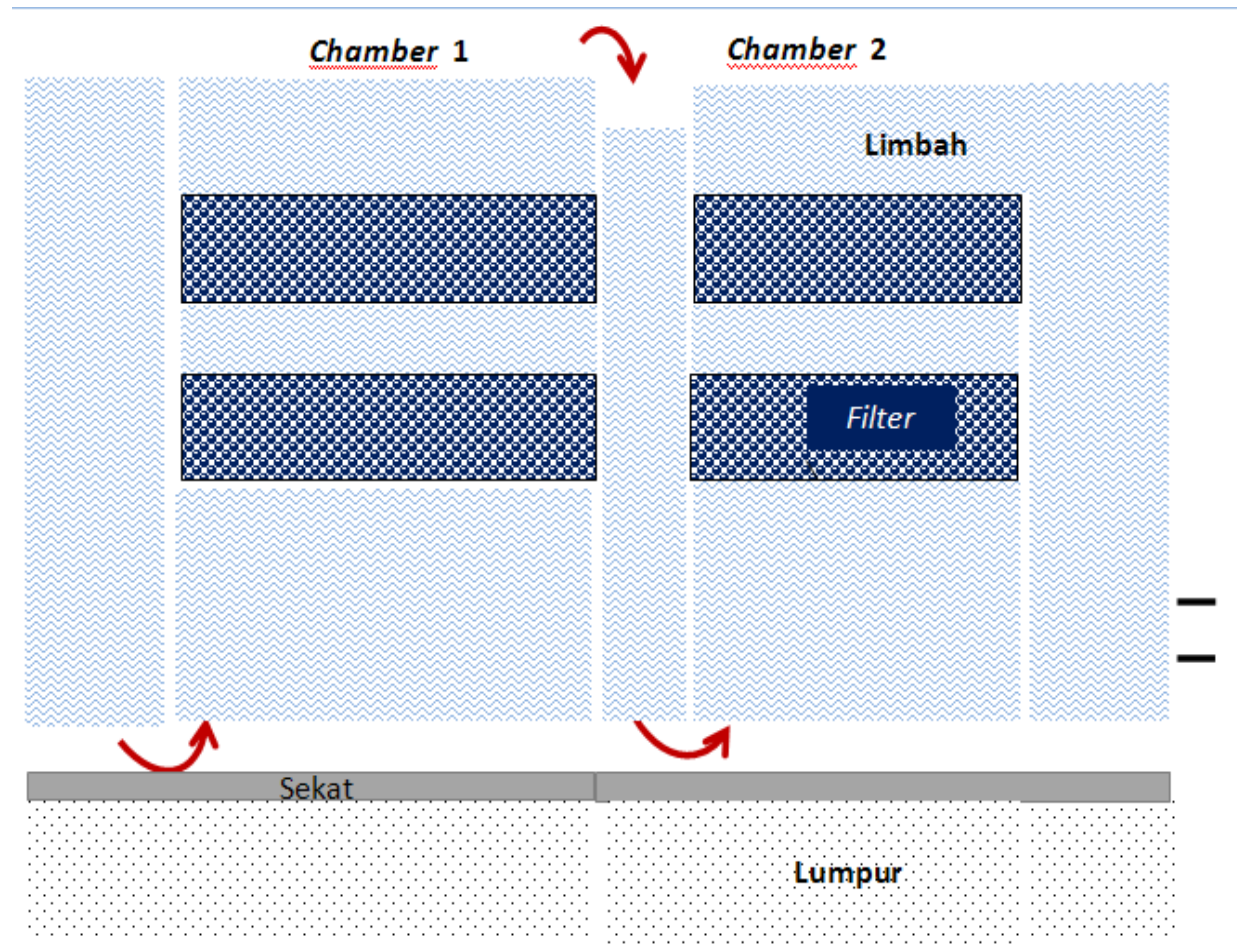

Gambar 2. Gambar Reaktor UAF. 